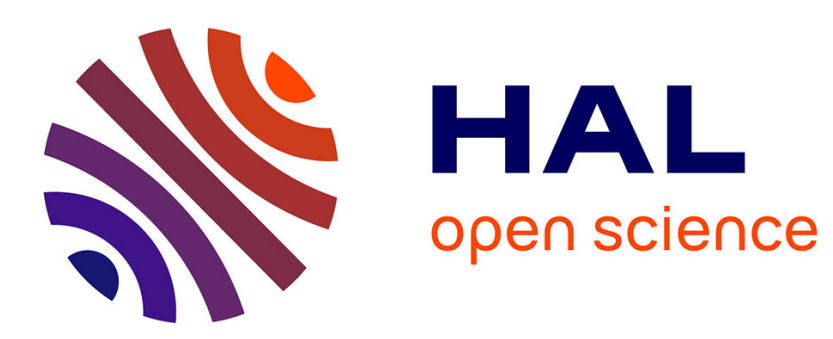

\title{
A new bipyridyl cobalt complex for reductive dechlorination of pesticides
}

W. Y. He, J. -M. Fontmorin, P. Hapiot, I. Soutrel, D. Floner, F. Fourcade, A. Amrane, Florence Geneste

\section{- To cite this version:}

W. Y. He, J. -M. Fontmorin, P. Hapiot, I. Soutrel, D. Floner, et al.. A new bipyridyl cobalt complex for reductive dechlorination of pesticides. Electrochimica Acta, 2016, 207, pp.313-320. 10.1016/j.electacta.2016.04.170 . hal-01310393

HAL Id: hal-01310393

https://hal-univ-rennes1.archives-ouvertes.fr/hal-01310393

Submitted on 21 Jun 2016

HAL is a multi-disciplinary open access archive for the deposit and dissemination of scientific research documents, whether they are published or not. The documents may come from teaching and research institutions in France or abroad, or from public or private research centers.
L'archive ouverte pluridisciplinaire HAL, est destinée au dépôt et à la diffusion de documents scientifiques de niveau recherche, publiés ou non, émanant des établissements d'enseignement et de recherche français ou étrangers, des laboratoires publics ou privés. 


\title{
A new bipyridyl cobalt complex for reductive dechlorination of pesticides
}

W. Y. He ${ }^{\mathrm{a}, \mathrm{b}}$, J.-M. Fontmorin ${ }^{\mathrm{a}, \mathrm{b}}$, P. Hapiot ${ }^{\mathrm{b}}$, I. Soutrel ${ }^{\mathrm{a}}$, D. Floner ${ }^{\mathrm{b}}$, F. Fourcade ${ }^{\mathrm{a}}$, A. Amrane ${ }^{\mathrm{a}}$, F. Geneste ${ }^{*}$ b

${ }^{a}$ Ecole Nationale Supérieure de Chimie de Rennes/Université de Rennes 1, CNRS, UMR 6226, 11 allée de Beaulieu, CS 50837, 35708 Rennes cedex 7, France.

${ }^{b}$ Université de Rennes 1, CNRS, UMR 6226, Equipe Matière Condensée et Systèmes Electroactifs, Campus de Beaulieu, 35042 Rennes cedex, France.

\begin{abstract}
Reductive dechlorinations are especially promising reactions for improving the biodegradability and hence decreasing the environmental impact of chlorinated organic pollutants. In this context, the catalytic activity of a bipyridyl cobalt complex containing two bipyridine ligands was examined for achieving clean electrochemical dehalogenation in aqueous media. The prepared $\left[\mathrm{Co}\left(\mathrm{bpy}\left(\mathrm{CH}_{2} \mathrm{OH}\right)_{2}\right)_{2}\right]^{2+}$ complex was found to exhibit high catalytic activity toward the dechlorination of chloroacetanilide herbicides. Based on preparative electrolyses, 2-electron reduction of the substrate was obtained with a dechlorination yield of $85 \%$, underlining the selectivity and efficiency of the dehalogenation process. Cyclic voltammetry analyses highlighted the catalytic activity of the complex toward chloroacetanilide herbicides, as alachlor, metolachlor and metazachlor. An high apparent chemical rate constant $k_{1}$ of $5000 \mathrm{~mol}^{-1} \mathrm{~L} \mathrm{~s}^{-1}$ is calculated for the first step of the cathodic reduction of alachlor, based on simulated cyclic voltammetry experiments.
\end{abstract}

Keywords: dehalogenation, chloroacetanilide, alachlor, Co complex, depollution

\section{Introduction}

Chlorinated organic compounds are widely used in synthetic chemistry and are prominent environmental contaminants as many of them are biorecalcitrant. Several physicochemical methods have been proposed for their degradation [1-6]. Among them, the catalytic reduction of chlorinated compounds has been the subject of numerous investigations because of its high importance both for synthetic chemistry and environment [6-11]. Transition metal complexes such as $\mathrm{Co}(\mathrm{I})$ complexes have been identified as effective catalysts for this

Corresponding author. E-mail address: Florence.Geneste@univ-rennes1.fr 
reaction [12-15], the reactivity of the catalyst depending on the ligands structure. [Co(salen) $]^{-}$ (salen=bis(salicyliden)ethylenediamine) has shown good catalytic activity toward alkyl iodide, bromide and chloride such as tert-butyl bromide and chloride [16], n-butyl bromide and iodide, 1,2-dibromobutane [17, 18], iodoethane [19], some of them containing a carbon in $\alpha$ position of a carbonyl (3-chloro-2,4-pentanedione) or a phenyl group ( $\mathrm{PhCCl}_{3}$ [14], benzal chloride [20, 21], and benzyl chlorides [22]). Whereas [Co(salen) $]^{-}$catalytic activity toward the reduction of bromobenzene has been reported once [23], it is not reported as a good catalyst for the reduction of aryl halides. Cobalt chelates of biological interest such as cobalt porphyrins, and cobalamin have shown good catalytic activity toward reduction of alkyl bromide and chlorine [24-26], ethylenes [27-29], and arenes [30-32]. Two different general mechanisms have been proposed for the catalysis depending on the ligand L, the halogenated compound and the electrolyte. These schemes differ by the nature of electron transfer step that involved the formation of the intermediate radical $\mathrm{R}$ (outer-sphere) or an oxidative addition (inner-sphere) (Scheme 1) [18, 27, 33-35].

Concerning the possible uses for an environmental purpose, some of these complexes have been reported to keep their catalytic activity in aqueous media, which is a requirement for such application [12, 24, 32, 36]. Among the possible catalysts, polypyridyl complexes of cobalt are promising candidates as they display good catalytic activity for indirect electroreduction of allyl chloride in aqueous medium [15, 37, 38]. However, the number of bipyridyl units coordinated to the metal strongly affects the catalytic behavior of the $\operatorname{Co}(\mathrm{I})$ polypyridyl complexes, such effect depending on the medium, electrolyte, substrates,... It was previously established that the catalytic behavior of $\operatorname{Co}($ bpy $) 3^{2+}$ toward the reduction of allyl chloride in acetonitrile involves the reduction of $\mathrm{Co}(\mathrm{II})$ to $\mathrm{Co}(\mathrm{I})$ followed by a rapid decomposition into $\mathrm{Co}(\mathrm{bpy}){ }_{2}{ }^{+}$(Scheme 2), the ligand dissociation step (Eq. 2) being the ratedetermining step and the $\mathrm{Co}(\mathrm{bpy}){ }_{2}{ }^{+}$being the active catalytic species $[39,40]$.

This conclusion was supported by the observation of a higher catalytic efficiency with $\mathrm{Co}(\mathrm{bpy}){ }_{2}{ }^{+}$than with $\mathrm{Co}(\mathrm{bpy}) 3_{3}{ }^{+}$. More recently, it was reported that $\mathrm{CoBr}_{2}$ in the presence of a single equivalent of 2,2 '-bipyridine or pyridine exhibits a high catalytic activity toward the reduction of aromatic halides [41, 42]. In an aqueous solution containing a surfactant, the reduced tris- complex was stabilized in the micelle and a mild kinetic enhancement was reported in the catalytic reduction of allyl halides by the Co(bpy $)_{3}{ }^{+}$complex. However, the exact nature of the active catalyst remains difficult to establish as little is known about the activity of the corresponding $\mathrm{Co}(\mathrm{bpy}){ }_{2}{ }^{+}$complex in such aqueous conditions. 
In this context, we have considered the catalytic activity toward dechlorination reaction of a new polypyridyl complex that contains only two bipyridyl units: $\left[\mathrm{Co}\left(\operatorname{bpy}\left(\mathrm{CH}_{2} \mathrm{OH}\right)_{2}\right)_{2}\right]^{2+}$ where bpy $\left(\mathrm{CH}_{2} \mathrm{OH}\right)_{2}$ is 4,4 '-Bis (hydroxymethyl)-2,2'-bipyridine. In view of potential environmental applications, its catalytic behavior was investigated in aqueous medium by cyclic voltammetry toward the reduction of several different common chlorinated pesticides. In complement to the cyclic voltammetry investigations, bulk electrolysis were also performed to precise the dependence of the catalytic efficiency on the structure of the chlorinated compound. The considered pesticides: alachlor 1, metazachlor $\mathbf{2}$, metolachlor 3, 2,4-D 4 and the dechlorinated form of alachlor 5, are shown in Scheme 3.

\section{Experimental section}

\subsection{Chemicals}

Alachlor (2-chloro- $N$-(2,6-diethylphenyl)- $N$-(methoxymethyl)acetamide), metazachlor (2chloro- $N$-(2,6-dimethylphenyl)- $N$-(1H-pyrazol-1-ylmethyl)acetamide), metolachlor (2-chloro$N$-(2-ethyl-6-methylphenyl)- $N$-(1-methoxypropan-2-yl)acetamide), $\quad$ [2,2'-bipyridine]-4,4'dicarboxylic acid, sodium borohydride and Cobalt(II) tetrafluoroborate hexahydrate were purchased from Sigma-Aldrich. 2,4-D (2-(2,4-dichlorophenoxy)acetic acid) and hexadecyl trimethyl ammonium bromide (HDTAB) were supplied by Alfa Aesar. Deschloroalachlor ( $N$ (2,6-diethylphenyl)- $N$-(methoxymethyl)acetamide) was obtained from Alpha Chimica (France). Graphite felt (Recycled Vein Graphite RVG 4000) was supplied by Mersen (France). Its specific area measured by the BET (Brunauer, Emett and Teller) method, its volume density and its carbon content were $0.7 \mathrm{~m}^{2} \mathrm{~g}^{-1}, 0.088 \mathrm{~g} \mathrm{~cm}^{-3}$ and $99.9 \%$, respectively.

\subsection{Synthetic procedures}

The following procedure for the preparation of [2,2'-bipyridine]-4,4'-diyldimethanol 8 was modified from literature conditions [43].

Synthesis of diethyl [2,2'-bipyridine]-4,4'-dicarboxylate 7. [2,2'-bipyridine]-4,4'dicarboxylic acid 6 (500 mg, $2 \mathrm{mmol}$ ) was added to absolute ethanol (40 mL). Concentrated sulfuric acid $(95 \%)(0.5 \mathrm{~mL})$ was added to the suspension and the mixture was refluxed for 4 days. The solution was cooled to room temperature, distilled water was added $(40 \mathrm{~mL})$ and ethanol was then evaporated. The $\mathrm{pH}$ was adjusted to 7 using a 5\% sodium hydroxide solution. The formed precipitate was filtrated and washed with water, leading to a white powder. Yield; 92\%, ${ }^{1} \mathrm{H}$ NMR $\left(\mathrm{CDCl}_{3}, 300 \mathrm{MHz}\right): \delta(\mathrm{ppm}) 1,38$ (t, 6H, J = $\left.7 \mathrm{~Hz}\right) ; 4.40$ (q, $4 \mathrm{H}, \mathrm{J}=7 \mathrm{~Hz}) ; 7.85$ (d, 2H, J = $6 \mathrm{~Hz}) ; 8.80$ (d, 2H, J=6 Hz); 8.88 (s, 2H). 
Synthesis of [2,2'-bipyridine]-4,4'-diyldimethanol 8. Sodium borohydride (1.87 g, 49 mmol) was added to a suspension of diethyl [2,2'-bipyridine]-4,4'-dicarboxylate 7 (567 mg, $1.89 \mathrm{mmol})$ dissolved in absolute ethanol $(34 \mathrm{~mL})$. The solution was refluxed for $3 \mathrm{~h}$. After cooling to room temperature, a saturated ammonium chloride solution $\left(24 \mathrm{~mL} / \mathrm{g}\right.$ of $\left.\mathrm{NH}_{4} \mathrm{Cl}\right)$ was added to decompose the excess of sodium borohydride. Ethanol was evaporated under vacuum and the resulting solid was dissolved in a minimum of water using ultrasonic bath. The solution was extracted with ethyl acetate $(5 \times 34 \mathrm{~mL})$, dried on sodium sulfate and concentrated under vacuum to give a white powder. Yield: $91 \%,{ }^{1} \mathrm{H}$ NMR $\left(\mathrm{CD}_{3} \mathrm{OD}, 300\right.$ MHz): $\delta(\mathrm{ppm}) 4.66(\mathrm{~s}, 4 \mathrm{H}) ; 7.35(\mathrm{~d}, 2 \mathrm{H}, \mathrm{J}=5 \mathrm{~Hz}) ; 8.18(\mathrm{~s}, 2 \mathrm{H}) ; 8.50$ (d, 2H, J = $5 \mathrm{~Hz})$.

Synthesis of $\left[\mathrm{Co}\left(\text { bpy }\left(\mathrm{CH}_{2} \mathrm{OH}\right)_{2}\right)_{2}\right]\left(\mathrm{BF}_{4}\right)_{2}$ 9. Cobalt(II) tetrafluoroborate hexahydrate (156 mg, $0.46 \mathrm{mmol}$ ) was added to 4,4'-Bis(hydroxymethyl)-2,2'-bipyridine 8 (408 mg, 1.89 mmol) dissolved in absolute ethanol $(37 \mathrm{~mL})$. The solution was refluxed under stirring for $24 \mathrm{~h}$, concentrated and dried under vacuum. The solid was dissolved in a minimum of methanol and dichloromethane was added slowly. The formed precipitate was filtrated and washed with dichloromethane, leading to a yellow solid. Yield: 95\%, HRMS (ESI): m/z calcd for $\mathrm{C}_{24} \mathrm{H}_{24} \mathrm{~N}_{4} \mathrm{O}_{4} \mathrm{Co}\left[\mathrm{M}-2 \mathrm{BF}_{4}\right]^{++}$: 245.5559; found, m/z 245.5559; Found, C, 43.68; H, 4.06; N, 8.27 Calc. for $\mathrm{C}_{24} \mathrm{H}_{24} \mathrm{BrCoF}_{8} \mathrm{~N}_{4} \mathrm{O}_{4}$ : C, 43.35; H, 3.64; N, 8.42\%.

\subsection{Dechlorination conditions.}

The dechlorination reaction was performed in a home-made flow cell [44]. To ensure a good homogeneity of the potential distribution in the three dimensional working electrode, the felt was located between two interconnected DSA counter-electrodes (dimentionally stable anodes, AC-2004, supplied by ECS International Electro Chemical Services, France). The compartments were separated by cationic exchange membranes (Ionac 3470 - Lanxess SAS, Courbevoie, France). The reference electrode (Mercury-mercurous sulfate - MSE) was positioned in the middle of the graphite felt $(10 \mathrm{~mm}$ diameter and $12 \mathrm{~mm}$ width $)$ and a potential of -1.8 V/MSE was applied using a VersaSTAT 3 potentiostat from Ametek/Princeton Applied (Elancourt, France). The solution $\left(100 \mathrm{mg} \mathrm{L}^{-1}\right.$ pesticide in $0.1 \mathrm{~mol}$ $\mathrm{L}^{-1} \mathrm{Na}_{2} \mathrm{SO}_{4}$ ) percolated the porous electrode at a flow rate of $1 \mathrm{~mL} \mathrm{~min}{ }^{-1}$ monitored by a Gilson minipuls 3 peristaltic pump (Middleton, WI, USA).

\subsection{Analytical procedures}

Electrochemical measurements. Voltammetric experiments were carried out using a VersaSTAT3 AMETEK Model (Princeton Applied Research) potentiostat/galvanostat. A glassy carbon electrode $\left(7 \mathrm{~mm}^{2}\right)$, a platinum plate auxiliary electrode, and a saturated calomel reference electrode were used in a standard three-electrode configuration. Cyclic voltammetry 
was carried out in $0.1 \mathrm{~mol} \mathrm{~L}^{-1} \mathrm{Na}_{2} \mathrm{SO}_{4}$, containing $0.1 \mathrm{~mol} \mathrm{~L}^{-1}$ hexadecyl trimethyl ammonium bromide (HDTAB) as cationic surfactant, under a dinitrogen atmosphere. For comparison with numerical simulations, the background was subtracted.

Numerical simulations of the voltammograms were performed with the KISSA 1D program10 using the default numerical options with the assumption of planar diffusion. Butler-Volmer law was considered for the electron transfer kinetics [45-47]. The transfer coefficient, $\alpha$, was taken as 0.5 , and the diffusion coefficients were estimated from voltammetric signals at different scan rates based on the Randles-Sevčik equation $\left(\left[\mathrm{Co}\left(\mathrm{bpy}\left(\mathrm{CH}_{2} \mathrm{OH}\right)_{2}\right)_{2}\right]\left(\mathrm{BF}_{4}\right)_{2}: 7.8 \times\right.$ $10^{-7} \mathrm{~cm}^{2} \mathrm{~s}^{-1}$; Alachlor: $3.2 \times 10^{-7} \mathrm{~cm}^{2} \mathrm{~s}^{-1}$ ).

High Performance Liquid Chromatography (HPLC). Alachlor concentration was determined by HPLC using a Waters 996 system equipped with waters 996 PDA (Photodiode Array Detector) and Waters 600 LCD Pump. The separation was achieved on a Waters C-18 $(5 \mu \mathrm{m} ; 4.6 \times 250 \mathrm{~mm})$ reversed-phase and the mobile phase consisted of a mixture of acetonitrile/ultra-pure water $(70 / 30, \mathrm{v} / \mathrm{v})$. The flow rate was set at $1 \mathrm{~mL} \mathrm{~min}^{-1}$ and $50 \mu \mathrm{L}$ injections were used. Detection was carried out at $230 \mathrm{~nm}$ and the retention time was approximately $8.3 \mathrm{~min}$.

The same apparatus with the same column were used to quantify 2,4-D. The mobile phase consisted of a mixture of acetonitrile/ultra-pure water $(60 / 40, v / v)$ and $0.1 \%$ Formic acid. Detection was carried out at $284 \mathrm{~nm}$ and the retention time was approximately $4.6 \mathrm{~min}$. Before HPLC analysis of alachlor and 2,4-D, the $\mathrm{pH}$ of the electrolyzed solutions should be raised at 2 .

Ultra-pressure liquid chromatography-MS/MS. The devices used are detailed in a previous work [4]. The analytes were separated by a Waters Acquity UPLC system (Waters corporation, Milford, MA, USA), consisting of an Acquity UPLC binary solvent manager, an Acquity UPLC sample manager and an Acquity UPLC column heater equipped with a Waters Acquity UPLC BEH C18 column $(2.1 \mathrm{~mm} \times 100 \mathrm{~mm}, 1.7 \mu \mathrm{m}$ particle size $)$ thermostated at 45 ${ }^{\circ} \mathrm{C}$ (Milford, MA, USA). Gradient LC elution was performed with $0.1 \%$ formic acid in $10 \%$ acetonitrile in ultrapure water as mobile phase $\mathrm{A}$ and acetonitrile added $0.1 \%(\mathrm{v} / \mathrm{v})$ of formic acid as mobile phase B. Separation of the analytes on the column was performed with a gradient of phase $\mathrm{A} / \mathrm{phase} \mathrm{B}$ at $0.4 \mathrm{~mL} \mathrm{~min}^{-1}$ flow rate. The starting eluent composition consisted of $100 \%$ phase A which was then linearly increased to reach $100 \%$ of phase B at 5 min. At $6.5 \mathrm{~min}$, the composition was changed again to $100 \%$ of phase A. The separated compounds were detected with a Waters Micromass Quattro Premier (Waters Corporation, Manchester, UK) triple quadripole mass spectrometer. It was operated with an electrospray 
source in positive ionization mode with a cone potential of $20 \mathrm{~V}$. The ionization source conditions were: capillary voltage of $3 \mathrm{kV}$, source temperature $120{ }^{\circ} \mathrm{C}$ and desolvation temperature $350{ }^{\circ} \mathrm{C}$. The cone and desolvation gas flows $\left(\mathrm{N}_{2}\right)$ were 50 and $750 \mathrm{~L} \mathrm{~h}^{-1}$, respectively. Analyses were performed in full scan mode. Spectra were acquired between 60 and $300 \mathrm{~m} / \mathrm{z}$ and the data were treated with Micromass MassLynx 4.1 software.

Ion chromatography. The concentration of chloride ions (diluted five times) before and after electrolysis were determined by DIONEX DX120 ion chromatography equipped with a conductivity detector and a DIONEX AS19 $(4 \times 250 \mathrm{~mm})$ ion-exclusion column. Potassium hydroxide was used as eluant and the flow rate was $1 \mathrm{~mL} \mathrm{~min}{ }^{-1}$. The detection was carried out by conductivity with a Self Regenerating Suppressor (SRS).

\section{Results and discussion}

\subsection{Synthesis and cyclic voltammetry analyses}

The ligand [2,2'-bipyridine]-4,4'-diyldimethanol 8 was synthesized from [2,2'-bipyridine]-4,4'dicarboxylic acid 6 by esterification and then reduction with $\mathrm{NaBH}_{4}(\mathrm{Scheme} 4)$ [48]

The $\left[\mathrm{Co}\left(\mathrm{bpy}\left(\mathrm{CH}_{2} \mathrm{OH}\right)_{2}\right)_{2}\right]^{2+}$ complex 9 was then prepared by refluxing 2 to 4 equivalents of [2,2'-bipyridine]-4,4'-diyldimethanol 8 with $\mathrm{Co}\left(\mathrm{BF}_{4}\right)_{2}$ in ethanol.

The redox behavior of the complex was first examined in aqueous medium in the presence of a surfactant to stabilize the $\left[\mathrm{Co}\left(\mathrm{bpy}\left(\mathrm{CH}_{2} \mathrm{OH}\right)_{2}\right)_{2}\right]^{+}$intermediate [37]. As seen in Figure 1, the voltammogram exhibits two well-defined reversible waves at 0.0 and $-1.2 \mathrm{~V}_{\mathrm{SCE}}$ corresponding respectively to the $\mathrm{Co}^{\mathrm{III} / \mathrm{II}}$ and $\mathrm{Co}^{\mathrm{II} / \mathrm{I}}$ systems (Fig. 1). It indicates that the different redox oxidation states of the complex are stable on the time scale of the cyclic voltammetry (some tens of seconds) and that the electron transfers kinetics are relatively fast in this medium. The complex synthesized in the presence of 4 equivalents of $\mathbf{8}$ exhibited the same two reversible systems, showing that the same complex is obtained even in the presence of an excess of ligand.

The redox behavior of the chlorinated pesticides, alachlor, metolachlor and metazachlor was examined in the same conditions. A broad and irreversible wave at a negative potential (around -1.4 V/SCE) close to the solvent discharge was visible as highlighted in Figure 2. 
Based on the general reactivity of halogenated alkyl-compounds, these different electrochemical peaks could be ascribed to the global 2-electron reduction of the $\mathrm{C}$-Cl bond leading to the corresponding dehalogenated form (Eq. 3) [49].

$$
\mathrm{R}-\mathrm{X}+2 \mathrm{e}^{-}+\mathrm{H}^{+} \rightarrow \mathrm{RH}+\mathrm{X}^{-}
$$

The catalytic activity of the $\left[\mathrm{Co}\left(\mathrm{bpy}\left(\mathrm{CH}_{2} \mathrm{OH}\right)_{2}\right)_{2}\right]^{2+}$ complex toward the reduction of chloroacetanilide pesticides of Scheme 3, was then examined by cyclic voltammetry. Addition of the chloroacetanilide pesticides to a solution of $\left[\mathrm{Co}\left(\mathrm{bpy}\left(\mathrm{CH}_{2} \mathrm{OH}\right)_{2}\right)_{2}\right]^{2+}$ led to a considerable increase of the cathodic peak current corresponding to the reduction of $\mathrm{Co}^{\mathrm{II}}$ in $\mathrm{Co}^{\mathrm{I}}$, while the reverse anodic peak decreased (Fig. 3).

The observed modifications (increase of the current and decrease of the reversibility at the level of the reduction) are indicative of a catalytic activity by the $\mathrm{Co}^{\mathrm{I}}$ complex toward the reduction of the chloroacetanilide herbicides.

Similar experiments were performed with an aromatic chlorine pesticide, 2,4-D (4) (Scheme 3). In the presence of 2,4-D, the cathodic wave of the $\mathrm{Co}^{\mathrm{II} / \mathrm{I}}$ system was enhanced while the anodic wave was totally suppressed (data not shown). Since direct reduction of 2,4$\mathrm{D}$ has been previously observed around $-1.5 \mathrm{~V}_{\mathrm{SCE}}$ and attributed to a one-electron reduction of carboxylic acid into carboxylate anion [50], it is difficult to conclude from these sole experiments on the catalytic activity of the $\mathrm{Co}^{\mathrm{I}}$ complex toward the dechlorination of 2,4-D.

\subsection{Exhaustive electrolysis}

To confirm the cyclic voltammetry analyses, the cathodic reduction of alachlor $\left(3.7 \times 10^{-4}\right.$ mol L $\mathrm{L}^{-1} ; 100 \mathrm{ppm}$ ) was performed at $-1.65 \mathrm{~V} / \mathrm{MSE}$ (i.e. $-1.25 \mathrm{~V} / \mathrm{SCE}$ ) in aqueous medium in the presence of the $\left[\mathrm{Co}\left(\operatorname{bpy}\left(\mathrm{CH}_{2} \mathrm{OH}\right)_{2}\right)_{2}\right]^{2+}$ complex. Notice that a Mercury Sulfate Electrode (MSE) was used as reference to avoid any pollution by chlorides during the ions solution analysis. The reaction was carried out in a flow electrochemical cell with recycling of the solution and with substrate to catalyst ratios of 3 and 4 . The working electrode is a graphite felt of $1 \mathrm{~cm}^{3}$. Interestingly, this material is available in larger scale as it is suitable for higher volumes of effluent to treat. The evolution of the solution composition was followed by regular sampling and HPLC and UPLC analyses. The variations of the normalized concentrations of alachlor and the corresponding dehalogenated product are presented in Figure 4, displayed for the most efficient substrate to catalyst ratio 3, as discussed below. A 
blank has been carried out in the same conditions for comparison. Direct reduction of alachlor occurred at $-1.65 \mathrm{~V} / \mathrm{MSE}$, leading to a degradation of alachlor of $27 \%$ (Table 1) with formation of deschloroalachlor 5 in $25 \%$.

As seen in Figure 4, deschloroalachlor 5, which exact structure has been confirmed by UPLC/MS/MS (see Supporting Information), is the only observed product during the electrochemical catalysis and its formation followed the degradation of alachlor with a final yield of $85 \%$, underlining the selectivity and the efficiency of the reduction process. Additionally, the final concentration of chloride ions was measured by ion chromatography (Table 1) at the end of the electrolyses and confirmed a total dechlorination of alachlor for a substrate/catalyst ratio of 3 . Concerning the faradic yield, a current efficiency of $55 \%$ was estimated from the charge passed during the electrolysis and considering a 2-electron reduction process and a total dechlorination. This value could probably be improved by an optimization of the cell. For comparison, a direct electrolysis without catalyst was also performed at $-1.8 \mathrm{~V} / \mathrm{MSE}$. A reduction of alachlor of $90 \%$ was obtained with a current efficiency of $17 \%$ due to the competition with hydrogen evolution at this potential. This result underlines the interest of the indirect catalytic process that occurs at lower potential. It is noticeable that the reduction of alachlor into deschloroalachlor proceeds via a 2-electron process using the $\left[\mathrm{Co}^{\mathrm{I}}\left(\mathrm{bpy}\left(\mathrm{CH}_{2} \mathrm{OH}\right)_{2}\right)_{2}\right]^{+}$complex, whereas the reduction with the corresponding tris-bypiridine analog has been reported as a monoelectronic process, leading to the formation of 1,5-hexadiene from allyl chloride [37, 38].

Similar experiments were carried out with $2,4-\mathrm{D}$ as a starting material. A potential of -1.8 V/MSE was applied for a concentration of $3.7 \times 10^{-4} \mathrm{~mol} \mathrm{~L}^{-1}(100 \mathrm{ppm})$ of 2,4-D and substrate to catalyst ratios of 2.5 and 2. Samples were taken from the solution during the electrolysis, acidified to $\mathrm{pH} 2$ and analyzed by HPLC for observing the evolution of 2,4-D concentration during the electrolysis as done previously for the reduction of alachlor. As seen in Figure 5, a decrease of the substrate concentration is observed upon electrolysis, leading to a degradation of 22 and $38 \%$ of 2,4-D for substrate to catalyst ratios of 2 and 2.5 , after $10 \mathrm{~h}$ of electrolysis, respectively. These results are much lower than those obtained for alachlor, underlining a poor catalytic activity of the $\left[\mathrm{Co}^{\mathrm{I}}\left(\mathrm{bpy}\left(\mathrm{CH}_{2} \mathrm{OH}\right)_{2}\right)_{2}\right]^{+}$catalyst toward the 2,4-D reduction. The reductive dechlorination of $2,4-\mathrm{D}$ is therefore possible at $-1.4 \mathrm{~V} / \mathrm{SCE}$ corresponding to the formation of the $\mathrm{Co}^{\mathrm{I}}$ complex but with a much lower efficiently than for the dechloration of alachlor. Our observations fall in line with literature reports about catalytic dechlorination in organic media. Indeed at the reduction potential of $\mathrm{Co}^{\mathrm{II}}(\mathrm{bpy}) 3^{2+}$ into 
$\mathrm{Co}^{\mathrm{I}}(\mathrm{bpy}) 3^{+}$, only an aliphatic chloride of 1,1-Bis(4-chlorophenyl)-2,2,2-trichloroethane was reduced [51], [52]. More recently, a study on $\mathrm{CoBr}_{2}$ bpy catalyst underlined the poor catalytic activity of the CoIBrbpy complex toward the reduction of aromatic chloride that was slightly enhanced by using Co ${ }^{0}$ bpy complex [42].

\subsection{Mechanistic study}

The reduction of chlorinated compounds has been previously reported as an outer-sphere or an inner-sphere mechanism depending on the substrate and media [18, 27, 33, 34]. To get some insights about the mechanism occurring in aqueous media with the studied chlorinated pesticides, the possibility of an outer-sphere mechanism was considered to realize if this class of complexes plays a more chemical role than to be a simple charge transfer mediator and thus how the structure of the complex is an important point in the efficiency of the catalysis. The voltammograms of the reduction of $\left[\mathrm{Co}^{\mathrm{II}}\left(\mathrm{bpy}\left(\mathrm{CH}_{2} \mathrm{OH}\right)_{2}\right)_{2}\right]^{2+}$ complex were recorded for different concentrations of alachlor and at different scan rates. As general observations, the cathodic peak current of the Co complex considerably increased with the concentration of alachlor in the range of investigated scan rates $\left(0.05-0.2 \mathrm{~V} \mathrm{~s}^{-1}\right)$. For the highest scan rates $\geq$ $0.1 \mathrm{~V} \mathrm{~s}^{-1}$, the voltammograms exhibit two reduction waves (see for example Fig. $6 \mathrm{~b}$ for a $2 \times$ $10^{-3} \mathrm{~mol} \mathrm{~L}^{-1}$ concentration of alachlor), the first one corresponding to the reduction of the $\mathrm{Co}^{\mathrm{II}}$ complex and the second one to the direct reduction of alachlor at the electrode. For the lowest scan rates, it is noticeable that the anodic peak corresponding to the oxidation of $\mathrm{Co}^{\mathrm{I}}$ into $\mathrm{Co}^{\mathrm{II}}$ remain visible even at high concentrations of alachlor $\left(12-20 \times 10^{-3} \mathrm{~mol} \mathrm{~L}^{-1}\right)$. This is indicative of a fast catalytic reaction since the catalyst was detected under its $\mathrm{Co}^{\mathrm{I}}$ form during the anodic scan and all alachlor was consumed (the direct reduction was not visible).

Simplified numerical simulations of the voltammograms were performed to derive an apparent charge transfer rate between the catalyst and the substrate RX $\left(k_{1}\right)$. The considered outer-sphere mechanism is presented on Scheme 5. It involves two monoelectronic charge transfers between the $\mathrm{Co}^{\mathrm{I}}$ catalyst and the substrate. The electrochemical apparent charge transfer standard rate constant $k_{s}$ was first estimated as $0.01 \mathrm{~cm} \mathrm{~s}^{-1}$ from the cyclic voltammetry of the reduction of $\left[\mathrm{Co}^{\mathrm{II}}\left(\mathrm{bpy}\left(\mathrm{CH}_{2} \mathrm{OH}\right)_{2}\right)_{2}\right]^{2+}$ complex, assuming a Buttler-Volmer law and considering the peak-to-peak potential separation between the cathodic and anodic 
scans [53]. The charge transfer coefficient was taken $\alpha=0.5$ and the diffusion coefficient of $\left[\mathrm{Co}^{\mathrm{II}}\left(\mathrm{bpy}\left(\mathrm{CH}_{2} \mathrm{OH}\right)_{2}\right)_{2}\right]^{2+}$ measured as $7.8 \times 10^{-7} \mathrm{~cm}^{2} \mathrm{~s}^{-1}$.

In a first series of simulation, the first reduction step was taken as the rate-determining step, all other steps being considered as fast $\left(k_{2}>>k_{1}\right.$, Fig. 7a). Within this simplification, it was not possible to get a proper fit between the simulated voltammograms and the experimental data (Fig. 7a), where the disappearance of the anodic wave already coincides with the increase of the cathodic peak current (for example, the reversibility character is almost lost for a $8 \times 10^{-3}$ mol L ${ }^{-1}$ concentration of alachlor, see Fig. 7a).

In a second set of simulations (Fig. 7b), the second reduction step, which is normally faster in outer-sphere mechanisms as the neutral radical is generally easier to reduce than the starting RX [54], was considered as a slow step. Only very low values of $k_{2}\left(<50 \mathrm{~mol}^{-1} \mathrm{~L} \mathrm{~s}^{-1}\right.$ i.e. $k_{2}<<k_{1}$ ) allow maintaining the presence of the anodic wave of the Co complex as the cathodic peak increases upon addition of alachlor. Under these conditions, the simulated voltammograms display a reasonable agreement with the experimental ones (Fig. 7b, see the supplementary material for an easier comparison). From these results, an apparent chemical rate constant $k_{1}$ of $5000 \mathrm{~mol}^{-1} \mathrm{~L} \mathrm{~s}^{-1}$ was estimated. It is worth noting that this value is 6 orders of magnitude higher than the apparent chemical rate constant estimated for the reduction of allyl chloride by the $\mathrm{Co}^{\mathrm{I}}(\mathrm{bpy}){ }_{3}{ }^{+}$complex $[15,37,38,55]$. It clearly underlines the high catalytic activity of the $\left[\mathrm{Co}^{\mathrm{I}}\left(\mathrm{bpy}\left(\mathrm{CH}_{2} \mathrm{OH}\right)_{2}\right)_{2}\right]^{+}$complex containing two bipyridyl ligands, toward dehalogenation of alachlor. The difficulty to fit the experimental voltammograms and the necessity for considering a slower second charge transfer suggest a more "chemical character" of the catalysis that was not considered owning to the complexity of the aqueous medium with surfactant.

\section{Conclusions}

This example of cobalt complex containing only two bipyridine ligands confirms all the interest of this class of molecules for achieving clean electrochemical dehalogenation of chlorinated pesticides. The prepared $\left[\mathrm{Co}\left(\mathrm{bpy}\left(\mathrm{CH}_{2} \mathrm{OH}\right)_{2}\right)_{2}\right]^{2+}$ complex exhibits high catalytic activity toward the dechlorination of chloroacetanilide herbicides. Based on preparative electrolyses performed on alachlor, 2-electron reduction of the substrate to deschloroalachlor was obtained with $85 \%$ of yield, underlining the high selectivity and efficiency of this dehalogenation process. We could highlight the high apparent chemical rate constant $k_{1}$ of 
$5000 \mathrm{~mol}^{-1} \mathrm{~L} \mathrm{~s}^{-1}$ followed by an apparent slower second reduction step. This observation suggests that the catalytic process is not a simple succession of electron transfer steps as the condition required on the second electronic transfer is not reasonable for a purely redox mediator. A more detailed study on the mechanism involving the Co complex will be envisaged in a simplified medium, with comparison with other cobalt complexes. The high catalytic activity of the Co complex containing two bipyridine ligands to achieve dechlorination of chloroacetanilide herbicides is particularly encouraging for applications in depollution processes. To still improve the performances of this dehalogenation process, work is currently in progress to investigate the catalytic activity of the $\left[\mathrm{Co}\left(\mathrm{bpy}\left(\mathrm{CH}_{2} \mathrm{OH}\right)_{2}\right)_{2}\right]^{2+}$ complex in heterogeneous conditions, avoiding by this way its presence in solution before a further biological treatment.

\section{Supporting information}

${ }^{1} \mathrm{H}-\mathrm{NMR}$ of intermediate products, mass spectrometry of the electrolyzed solution and of deschloroalachlor and comparison of the experimental results and simulations obtained in cyclic voltammetry.

\section{Acknowledgments}

Profs. I Svir and C. Amatore are warmly thanked for providing us the KISSA 1D software package, which was used for the mechanistic simulations of the voltammograms. W. Y. He thanks the China Scholarship Council for a Ph.D grant.

\section{References}

[1] J. Gonzalez-Garcia, V. Saez, I. Tudela, M.I. Diez-Garcia, M.D. Esclapez, O. Louisnard, Sonochemical treatment of water polluted by chlorinated organocompounds. A review, Water, 2 (2000) 28-74.

[2] J. Liang, S. Komarov, N. Hayashi, E. Kasai, Recent trends in the decomposition of chlorinated aromatic hydrocarbons by ultrasound irradiation and Fenton's reagent, J. Mater. Cycles Waste Manage, 9 (2007) 47-55.

[3] K. Pirkanniemi, M. Sillanpää, Heterogeneous water phase catalysis as an environmental application: a review, Chemosphere, 48 (2002) 1047-1060.

[4] J.-M. Fontmorin, S. Huguet, F. Fourcade, F. Geneste, D. Floner, A. Amrane, Electrochemical oxidation of 2,4-Dichlorophenoxyacetic acid: Analysis of by-products and improvement of the biodegradability, Chem. Eng. J., 195-196 (2012) 208-217. 
[5] J.-M. Fontmorin, F. Fourcade, F. Geneste, D. Floner, S. Huguet, A. Amrane, Combined process for 2,4-Dichlorophenoxyacetic acid treatment - Coupling of an electrochemical system with a biological treatment, Biochem. Eng. J., 70 (2013) 17-22.

[6] J.-M. Fontmorin, J. Siguie, F. Fourcade, F. Geneste, D. Floner, I. Soutrel, A. Amrane, Combined electrochemical treatment / biological process for the removal of a commercial herbicide solution, U46D, Sep. Purif. Technol., 132 (2014) 704-711.

[7] I.M. Freidel, A.C. Frost, K.J. Herbert, F.J. Meyer, J.C. Summers, New catalyst technologies for the destruction of halogenated hydrocarbons and volatile organics, Catal. Today, 17 (1993) 367-382.

[8] S. Ordonez, H. Sastre, F.V. Diez, Abatement of chlorinated pollutants in organic wastes using catalytic hydrodechlorination, Recent Res. Dev. Chem. Eng., 4 (2000) 327-339.

[9] F.-D. Kopinke, D. Angeles-Wedler, D. Fritsch, K. MacKenzie, Pd-catalyzed hydrodechlorination of chlorinated aromatics in contaminated waters - Effects of surfactants, organic matter and catalyst protection by silicone coating, Appl. Catal. B: Environ., 96 (2010) 323-328.

[10] J.M. Fritsch, K. McNeill, Aqueous Reductive Dechlorination of Chlorinated Ethylenes with Tetrakis(4-carboxyphenyl)porphyrin Cobalt, Inorg. Chem., 44 (2005) 4852-4861.

[11] K.M. McCauley, S.R. Wilson, W.A. van der Donk, Synthesis and Characterization of Chlorinated Alkenylcobaloximes To Probe the Mechanism of Vitamin B12-Catalyzed Dechlorination of Priority Pollutants, Inorg. Chem., 41 (2002) 393-404.

[12] L. Ukrainczyk, M. Chibwe, T.J. Pinnavaia, S.A. Boyd, Reductive Dechlorination of Carbon Tetrachloride in Water Catalyzed by Mineral-Supported Biomimetic Cobalt Macrocycles, Environ. Sci. Technol., 29 (1995) 439-445.

[13] S. Kliegman, K. McNeill, Dechlorination of chloroethylenes by cob(I)alamin and cobalamin model complexes, Dalton trans., (2008) 4191-4201.

[14] S.A. Kaufman, T. Phanijphand, A.J. Fry, Cobalt(salen)-Electrocatalyzed Conversion of Benzotrichloride Into Tolane. A Triply Catalytic and Overall Quintuple Electrochemical Transformation, Tetrahedron Lett., 37 (1996) 8105-8108.

[15] G. Muthuraman, K.C. Pillai, Dechlorination of beta-methylallyl chloride by electrogenerated $\left[\mathrm{Co}(\mathrm{I})(\text { bipyridine })_{3}\right]^{+}$: An electrochemical study in the presence of cationic surfactants, J. Colloid Interface Sci., 297 (2006) 687-695.

[16] A. Puxeddu, G. Costa, N. Marsich, Reaction of Electrogenerated [CoI(salen)] with tButyl Bromide and t-Butyl Chloride, Dalton Trans., (1980) 1489-1493. 
[17] D. Pletcher, H. Thompson, Influence of electrolyte concentration on coupled chemical reactions Part 1 Reduction of CoII(salen) in aprotic solvents, J. Chem. Soc., Faraday Trans., 93 (1997) 3669-3675.

[18] D. Pletcher, H. Thompson, A microelectrode study of the catalysis of alkyl halide reduction by Co(II)(salen), J. Electroanal. Chem., 464 (1999) 168-175.

[19] K.S. Alleman, D.G. Peters, Catalytic reduction of iodoethane by cobalt(I) salen electrogenerated at vitreous carbon cathodes, J. Electroanal. Chem., 451 (1998) 121-128.

[20] A.J. Fry, A.H. Singh, Cobalt(salen)-Electrocatalyzed Reduction of Benzal Chloride. Dependence of Products upon Electrolysis Potential, J. Org. Chem., 59 (1994) 8172-8177.

[21] A.J. Fry, U.N. Sirisoma, A.S. Lee, Conversion of Benzal Chloride to Stilbene by Electrogenerated Cobalt(I)(Salen) A Doubly Electrocatalytic Process, Tetrahedron Lett., 34 (1993) 809-812.

[22] A.A. Isse, A. Gennaro, E. Vianello, Mechanism of the electrochemical reduction of benzyl chlorides catalysed by Co(salen), J. Electroanal. Chem., 444 (1998) 241-245.

[23] G. Costa, A. Puxeddu, E. Reisenhofer, Reactions of Cobalt(I) Complexes with Ammonium and Sulphonium Ions and Organic Halides, Dalton Trans., (1973) 2034-2039.

[24] T.S. Marks, A. Maule, The use of immobilized porphyrins and corrins to dehalogenate organochlorine pollutants, Appl. Microbiol. Biotechnol., 38 (1992) 413-416.

[25] B. Kräutler, T. Dérer, P. Liu, W. Mühlecker, M. Puchberger, K. Gruber, C. Kratky, Oligomethylene-Bridged Vitamin B 12 Dimers, Angew. Chem. Int. Ed. Engl., 34 (1995) 84-86.

[26] G. Zheng, M. Stradiotto, L. Li, An electrochemical and spectroelectrochemical (IR) investigation of the reduction of RCo(II)TPP (R-benzyl or butyl; TPP-tetraphenylporphyrin): mechanistic implications in the CoTPP catalyzed electrocarboxylation of alkyl halides, J. Electroanal. Chem., 453 (1998) 79-88.

[27] S. Kliegman, K. McNeill, Dechlorination of chloroethylenes by cob(I)alamin and cobalamin model complexes, Dalton Trans., (2008) 4191-4201.

[28] A.D. Follett, K. McNeill, Reduction of Trichloroethylene by Outer-Sphere ElectronTransfer Agents, J. Am. Chem. Soc., 127 (2005) 844-845.

[29] R. Scheffold, S. Abrecht, R. Orlinski, H.-R. Ruf, P. Stamouli, O. Tinembart, L. Walder, C. Weymuth, Vitamin B12-mediated electrochemical reactions in the synthesis of natural products, Pure Appl. Chem., 59 (1987) 363-372.

[30] N. Assaf-Anid, L. Nies, T.M. Vogel, Reductive Dechlorination of a Polychlorinated Biphenyl Congener and Hexachlorobenzene by Vitamin B12, Appl. Environ. Microbiol., 58 (1992) 1057-1060. 
[31] M.H. Smith, S.L. Woods, Regiospecificity of Chlorophenol Reductive Dechlorination by Vitamin B12,, Appl. Environ. Microbiol., 60 (1994) 4111-4115.

[32] S.L. Woods, D.J. T robaugh, Polychlorinated Biphenyl Reductive Dechlorination by Vitamin B12s: Thermodynamics and Regiospecificity, Environ. Sci. Technol., 33 (1999) $857-$ 863.

[33] D. Pletcher, H. Thompson, Influence of electrolyte concentration on coupled chemical reactions Part 1 Reduction of CoII(salen) in aprotic solvents, J. Chem. Soc., Faraday T rans., 93 (1997) 3669-3675.

[34] C. Costentin, M. Robert, J.-M. Savéant, Does Catalysis of Reductive Dechlorination of Tetra- and Trichloroethylenes by Vitamin B12 and Corrinoid-Based Dehalogenases Follow an Electron Transfer Mechanism?, J. Am. Chem. Soc., 127 (2005) 12154-12155.

[35] C. Costentin, G. Passard, M. Robert, J.-M. Savéant, Concertedness in proton-coupled electron transfer cleavages of carbon-metal bonds illustrated by the reduction of an alkyl cobalt porphyrin, Chem. Sci., 4 (2013) 819-823.

[36] T.S. Marks, J.D. Allpress, A. Maule, Dehalogenation of Lindane by a variety of Porphyrins and Corrins, Appl. Environ. Microbiol., 55 (1989) 1258-1261.

[37] G.N. Kamau, J.F. Rusling, Electrocatalytic reactions in organized assemblies Part III. Reduction of allyl halides by bibyridyl derivatives of cobalt in anionic and cationic micelles, J. Electroanal. Chem., 240 (1988) 217-226.

[38] C. Shi, J.F. Rusling, Z. Wang, W.S. Willis, A.M. Winiecki, S.L. Suib, Electrocatalytic Reactions in Organized Assemblies. 6. Electrochemical and Spectroscopic Studies of Catalytic Clay/Micelle Electrodes, Langmuir, 5 (1989) 650-660.

[39] S. Margel, F.C. Anson, Catalysis of the Electroreduction of Allyl Chloride by Cobalt 2,2'-Bipyridine Complexes, J. Electrochem. Soc., 125 (1978) 1232-1235.

[40] S. Margel, W. Smith, F.C. Anson, Electrochemistry of 2,2'-Bipyridine Complexes of Cobalt in the Presence of Acrylonitrile, J. Electrochem. Soc., 125 (1978) 241-246.

[41] K. Kecili, O. Buriez, E. Labbé, J. Périchon, On the reactivity of the electrogenerated cobalt(I) species towards aryl halides in the presence of allylethers, Electrochem. Acta, 50 (2005) 2377-2384.

[42] L. Polleux, E. Labbé, O. Buriez, J. Périchon, CoI- and Co0-Bipyridine Complexes Obtained by Reduction of $\mathrm{CoBr}_{2}$ bpy: Electrochemical Behaviour and Investigation of Their Reactions with Aromatic Halides and Vinylic Acetates, Chem. Eur. J., 11 (2005) 4678-4686. 
[43] M. Chandrasekharam, C. Srinivasarao, T. Suresh, M.A. Reddy, M. Raghavender, G. Rajkumar, M. Srinivasu, P.Y. Reddy, High spectral response heteroleptic ruthenium (II) complexes as sensitizers for dye sensitized solar cells, J. Chem. Sci., 123 (2011) 37-46.

[44] J.-M. Fontmorin, W.Y. He, D. Floner, F. Fourcade, A. Amrane, F. Geneste, Reductive dehalogenation of 1,3-dichloropropane by a [Ni(tetramethylcyclam)]Br2-Nafion ${ }^{\circledR}$ modified electrode, Electrochem. Acta, 137 (2014) 511-517.

[45] See the following website for KISSA 1D software: www.kissagroup.com.

[46] C. Amatore, O. Klymenko, I. Svir, A New Strategy for Simulation of Electrochemical Mechanisms Involving Acute Reaction Fronts in Solution: Application to Model Mechanisms., Electrochem. Commun., 12 (2010) 1165-1169.

[47] C. Amatore, O. Klymenko, I. Svir, A New Strategy for Simulation of Electrochemical Mechanisms Involving Acute Reaction Fronts in Solution: Principle., Electrochem. Commun., 12 (2010) 1170-1173.

[48] M. Chandrasekharam, C. Srinivasarao, T. Suresh, M.A. Reddy, M. Raghavender, G. Rajkumar, M. Srinivasu, P.Y. Reddy, High spectral response heteroleptic ruthenium(II) complexes as sensitizers for dye sensitized solar cells, J. Chem. Sci., 123 (2011) 37-46.

[49] H. Lund, O. Hammerich, Organic Electrochemistry, Marcel Dekker, New York, 2001.

[50] J.-M. Fontmorin, F. Fourcade, F. Geneste, I. Soutrel, D. Floner, A. Amrane, Direct electrochemical oxidation of a pesticide, 2,4-Dichlorophenoxyacetic acid, at the surface of a graphite-felt electrode - Biodegradability improvement, C. R. Chim., 18 (2015) 32-38.

[51] M.O. Iwunze, J.F. Rusling, Aqueous lamellar surfactant system for mediated electrolytic dechlorination of polychlorinated biphenyls, J. Electroanal. Chem., 266 (1989) 197-201.

[52] S. Schweizer, J.F. Rusling, Q. Huang, Electrolytic Dechlorination of DDT In a Bicontinuous Microemulsion, Chemosphere, 28 (1994) 961-970.

[53] A.J. Bard, L.R. Faulkner, Electrochemical Methods: Fundamentals and Applications, John Wiley \& Sons, Inc, New York, 2001.

[54] J.-M. Saveant, Elements of Molecular and Biomolecular Electrochemistry: An Electrochemical Approach to Electron Transfer Chemistry, Wiley-Interscience, New Jersey, 2006.

[55] M. Govindan, I.-S. Moon, Aqueous Co(I) Stabilized Micellar Solution for Catalysis: A Mediated Electrocatalytic Reduction study on Perchloroethylene, Int. J. Electrochem. Sci., 8 (2013) 3039-3048. 


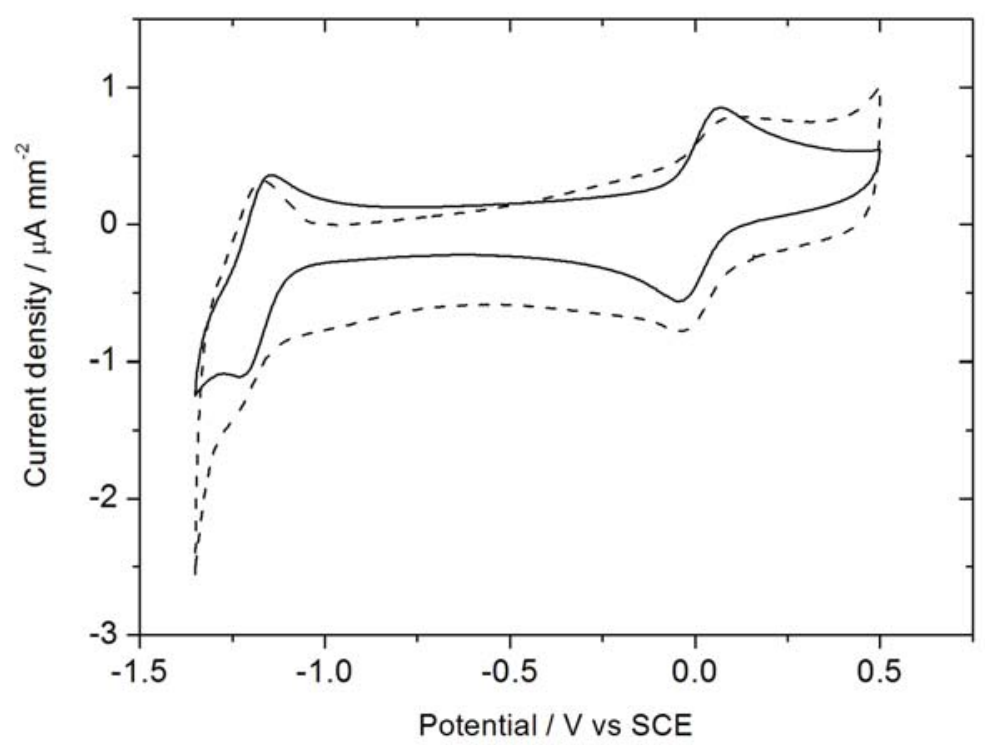

Figure 1. Cyclic voltammograms on a $3 \mathrm{~mm}$ diameter glassy carbon electrode in water $+0.1 \mathrm{~mol} \mathrm{~L}^{-1} \mathrm{Na}_{2} \mathrm{SO}_{4}+$ $0.1 \mathrm{~mol} \mathrm{~L}-1$ HDTAB of $1.9 \times 10^{-3} \mathrm{~mol} \mathrm{~L}^{-1}$ of $\left[\mathrm{Co}\left(\mathrm{bpy}\left(\mathrm{CH}_{2} \mathrm{OH}\right)_{2}\right)_{2}\right]^{2+}$ prepared from $2(----)$ and $4(-)$ eq. of [2,2'-bipyridine]-4,4'-diyldimethanol 8. Scan rate $0.02 \mathrm{~V} \mathrm{~s}^{-1}$.

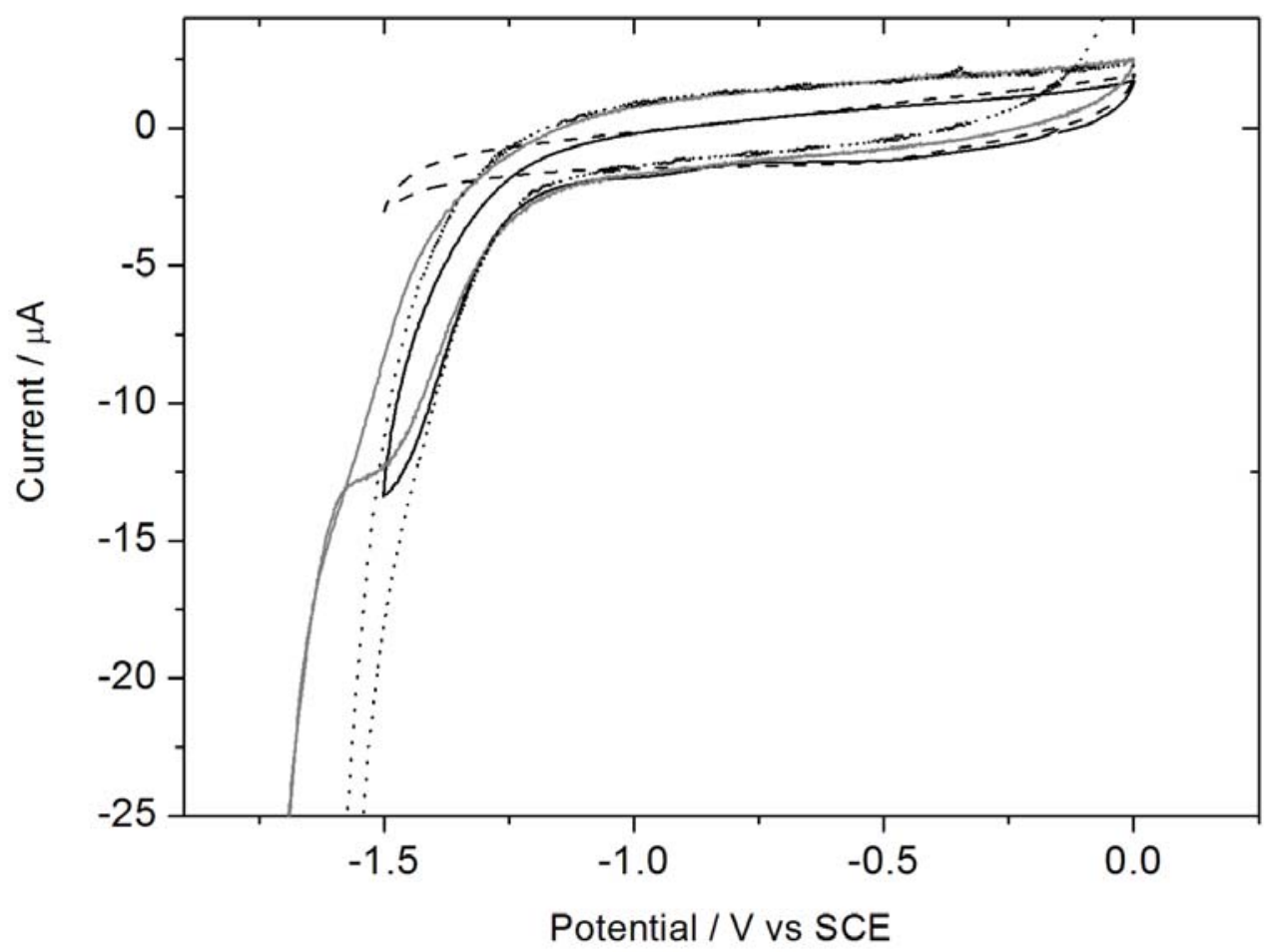

Figure 2. Cyclic voltammograms in $0.1 \mathrm{~mol} \mathrm{~L}^{-1} \mathrm{Na}_{2} \mathrm{SO}_{4}+0.1 \mathrm{~mol} \mathrm{~L}{ }^{-1} \mathrm{HDTAB}$ without (----) and with $4 \times 10^{-3}$ mol L-1 alachlor (—), $4 \times 10^{-3}$ mol L-1 metazachlor $\left({ }_{-}\right), 4 \times 10^{-3} \mathrm{~mol} \mathrm{~L}^{-1}$ metolachlor $(\ldots \ldots)$ on a $3 \mathrm{~mm}$ diameter glassy carbon electrode. Scan rate $0.02 \mathrm{~V} \mathrm{~s}^{-1}$ 

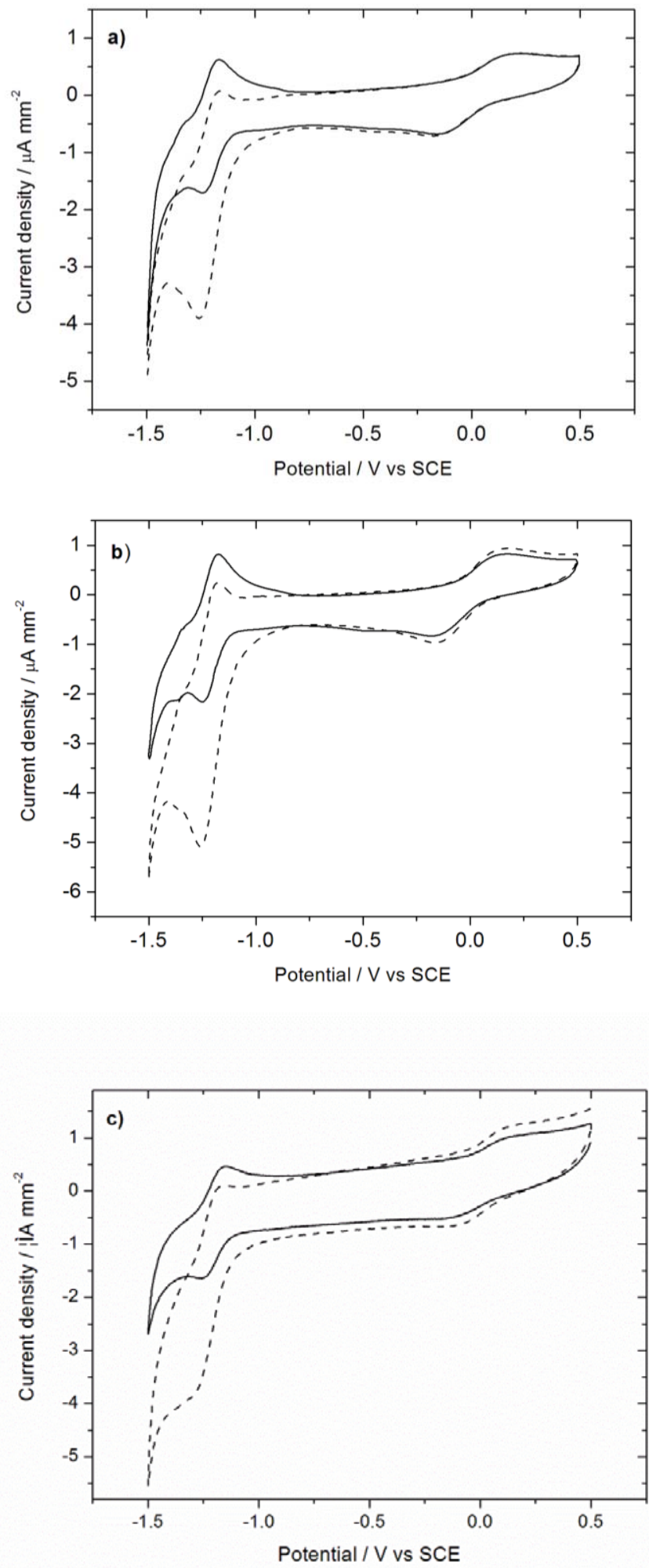

Figure 3. Cyclic voltammograms on a $3 \mathrm{~mm}$ diameter glassy carbon electrode of $\left[\mathrm{Co}\left(\mathrm{bpy}\left(\mathrm{CH}_{2} \mathrm{OH}\right)_{2}\right)_{2}\right]^{2+}$ complex $\left(1.9 \times 10^{-3} \mathrm{~mol} \mathrm{~L}^{-1}\right)$ in $0.1 \mathrm{~mol} \mathrm{~L}^{-1} \mathrm{Na}_{2} \mathrm{SO}_{4}+0.1 \mathrm{~mol} \mathrm{~L}^{-1} \mathrm{HDTAB}$ before (-) and after (----) addition of a) $4 \times 10^{-3} \mathrm{~mol} \mathrm{~L}^{-1}$ alachlor b) $4 \times 10^{-3} \mathrm{~mol} \mathrm{~L}^{-1}$ metazachlor c) $3.9 \times 10^{-3} \mathrm{~mol} \mathrm{~L}^{-1}$ metolachlor. Scan rate $0.1 \mathrm{~V}$ $\mathrm{s}^{-1}$. 

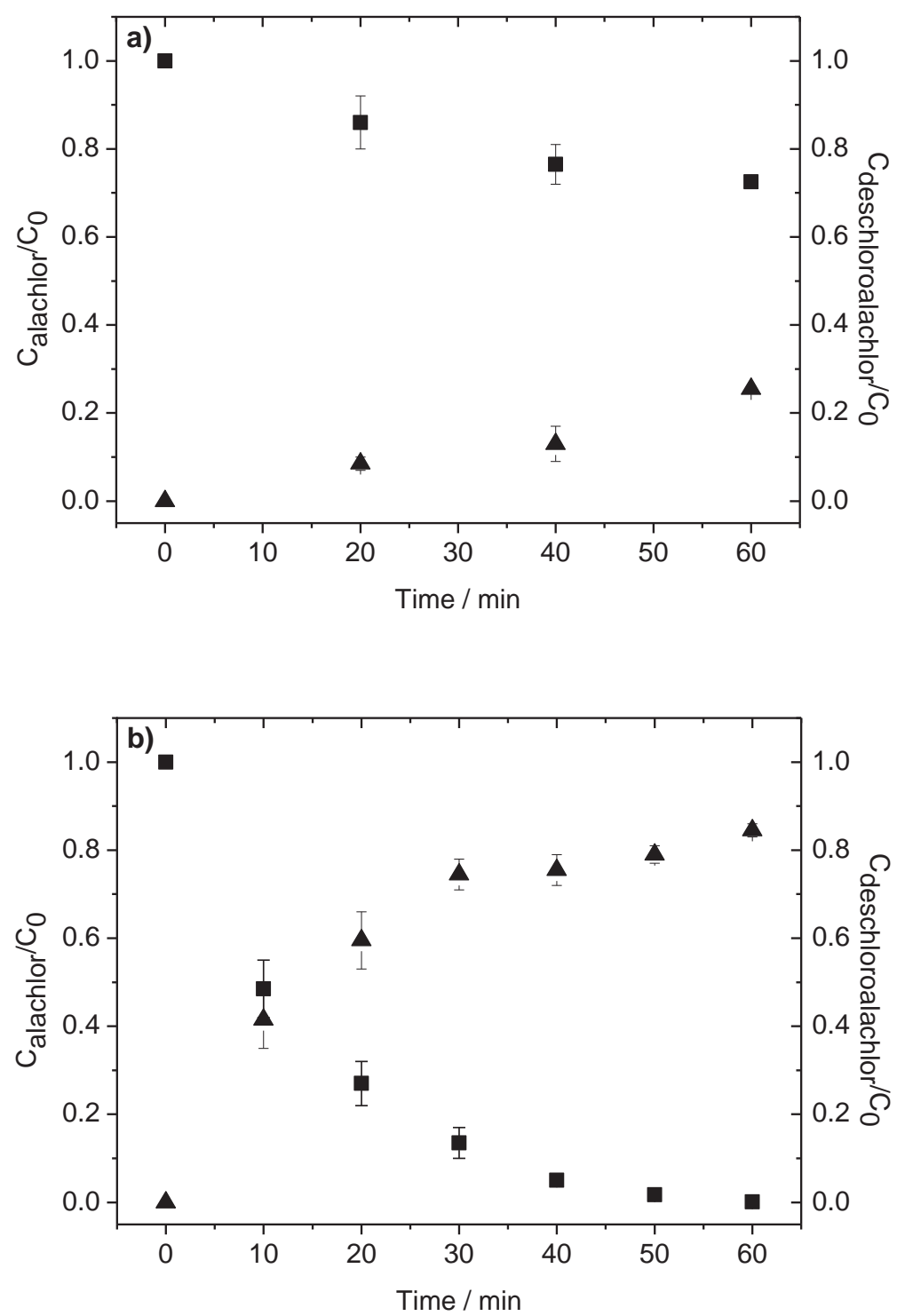

Figure 4: Exhaustive electrolysis. Evolution of the normalized concentration $C / \mathrm{C}_{0}$ of alachlor $(-)$ and deschloroalachlor $(\boldsymbol{\Delta}) v s$ electrolysis time for the cathodic reduction of alachlor $\left(3.7 \times 10^{-4} \mathrm{~mol} \mathrm{~L}^{-1} ; 100 \mathrm{ppm}\right)$ performed at $-1.65 \mathrm{~V} / \mathrm{MSE}$ (equivalent to $-1.25 \mathrm{~V} / \mathrm{SCE}$ ) in $0.1 \mathrm{~mol} \mathrm{~L}^{-1} \mathrm{Na}_{2} \mathrm{SO}_{4}$ without a) and with $1.24 \times 10^{-4}$ mol L-1 $\left[\mathrm{Co}\left(\mathrm{bpy}\left(\mathrm{CH}_{2} \mathrm{OH}\right)_{2}\right)_{2}\right]^{2+}$ b) at $1 \mathrm{~mL} \mathrm{~min}^{-1}$. $\mathrm{C}_{\text {alachlor }}$ and $\mathrm{C}_{\text {deschloroalachlor }}$ are the concentrations of alachlor and deschloroalachlor at a given time and $\mathrm{C}_{0}$ the initial concentration of alachlor. Error bars are based on two reproducibility measurements. 


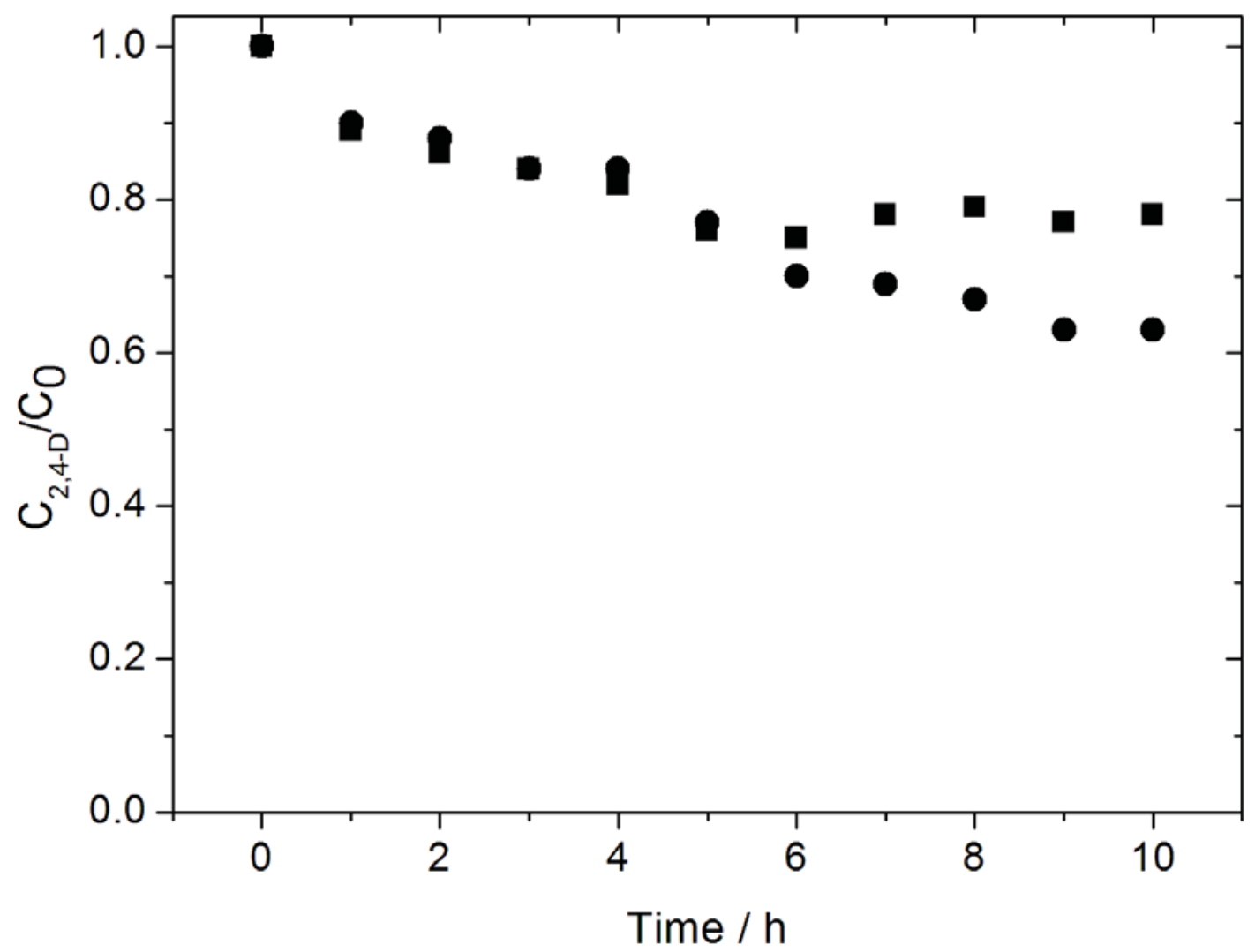

Figure 5. Exhaustive electrolysis. Evolution of the normalized concentration $\mathrm{C}_{2,4-\mathrm{D}} / \mathrm{C}_{0}$ vs electrolysis time for the cathodic reduction of 2,4-D $\left(4.5 \times 10^{-4} \mathrm{~mol} \mathrm{~L}^{-1}\right)$ performed with $\left[\mathrm{Co}\left(\mathrm{bpy}\left(\mathrm{CH}_{2} \mathrm{OH}\right)_{2}\right)_{2}\right]^{2+}\left(2.3 \times 10^{-4} \mathrm{~mol} \mathrm{~L}^{-1}\right.$ $\left.(\bullet) ; 1.8 \times 10^{-4} \mathrm{~mol} \mathrm{~L}^{-1}(\bullet)\right)$ in $0.1 \mathrm{~mol} \mathrm{~L}^{-1} \mathrm{Na}_{2} \mathrm{SO}_{4}\left(\mathrm{pH}=7.2,1 \mathrm{~mL} \mathrm{~min}^{-1}\right)$. 

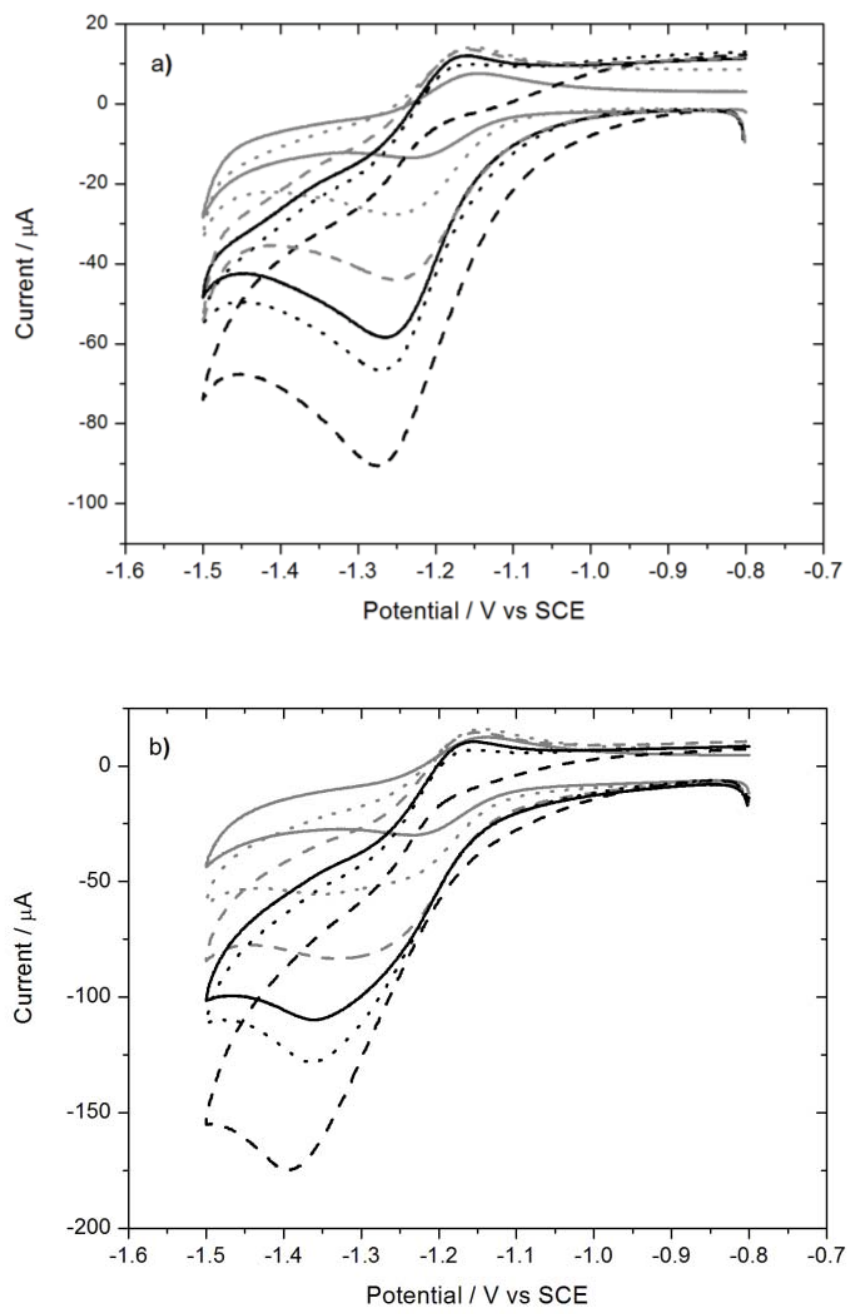

Figure 6. Cyclic voltammograms of $\left[\mathrm{Co}\left(\text { bpy }\left(\mathrm{CH}_{2} \mathrm{OH}\right)_{2}\right)_{2}\right]^{2+}$ complex $\left(1.9 \times 10^{-3} \mathrm{~mol} \mathrm{~L}^{-1}\right)$ in $0.1 \mathrm{~mol} \mathrm{~L}^{-1} \mathrm{Na}_{2} \mathrm{SO}_{4}$ $+0.1 \mathrm{~mol} \mathrm{~L}^{-1}$ HDTAB before (-) and after addition of $2 \times 10^{-3} \mathrm{~mol} \mathrm{~L}^{-1}(\ldots \ldots), 4 \times 10^{-3} \mathrm{~mol} \mathrm{~L}^{-1}(----), 8 \times 10^{-3}$ mol L-1 (-), $12 \times 10^{-3} \mathrm{~mol} \mathrm{~L}^{-1}(\ldots .),. 20 \times 10^{-3} \mathrm{~mol} \mathrm{~L}^{-1}$ (----) alachlor on a $3 \mathrm{~mm}$ diameter glassy carbon electrode at a) $0.05 \mathrm{~V} \mathrm{~s}^{-1}$ and b) Scan rate $0.2 \mathrm{~V} \mathrm{~s}^{-1}$. The background was subtracted. 

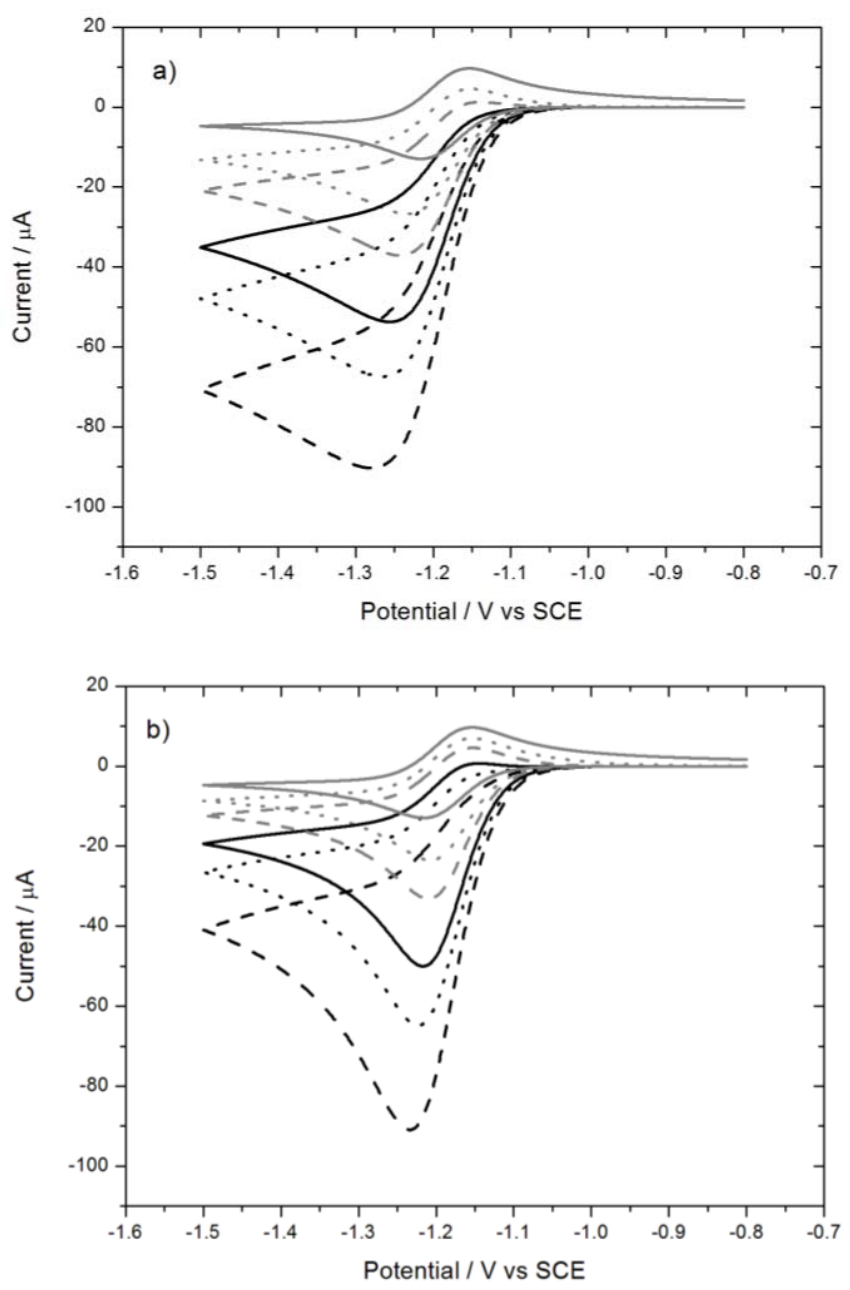

Figure 7. Simulations of voltammograms of Figure 6 a considering the second reduction step as a) fast $k_{2}>>k_{1}$ and b) low $k_{2}<<k_{1}=5000 \mathrm{~mol}^{-1} \mathrm{~L} \mathrm{~s}^{-1}\left[\mathrm{Co}\left(\operatorname{bpy}\left(\mathrm{CH}_{2} \mathrm{OH}\right)_{2}\right)_{2}\right]^{2+}$ complex $\left(1.9 \times 10^{-3} \mathrm{~mol} \mathrm{~L}^{-1}\right)$ in $0.1 \mathrm{~mol} \mathrm{~L}^{-1}$ $\mathrm{Na}_{2} \mathrm{SO}_{4}+0.1 \mathrm{~mol} \mathrm{~L}{ }^{-1} \mathrm{HDTAB}$ before $(-)$ and after addition of $2 \times 10^{-3} \mathrm{~mol} \mathrm{~L}^{-1}(\ldots \ldots), 4 \times 10^{-3} \mathrm{~mol} \mathrm{~L}^{-1}(-----)$, $8 \times 10^{-3} \mathrm{~mol} \mathrm{~L}^{-1}(-), 12 \times 10^{-3} \mathrm{~mol} \mathrm{~L}^{-1}(\ldots),. 20 \times 10^{-3} \mathrm{~mol} \mathrm{~L}^{-1}(----)$ alachlor on a $3 \mathrm{~mm}$ diameter glassy carbon electrode at $0.05 \mathrm{~V} \mathrm{~s}^{-1}$. 
Scheme 1. Inner-sphere and outer-sphere mechanisms of dehalogenation reactions catalyzed by $\mathrm{Co}^{\mathrm{I}}$ complexes.

$$
\begin{aligned}
& {\left[\mathrm{Co}^{\mathrm{I}}(\mathrm{L})\right]^{-}+\mathrm{RX} \rightarrow\left[\mathrm{Co}^{\mathrm{III}} \mathrm{R}(\mathrm{L})\right]+\mathrm{X}^{-}(\text {Inner-sphere) }} \\
& \left.\left[\mathrm{Co}^{\mathrm{I}}(\mathrm{L})\right]^{-}+\mathrm{RX} \rightarrow\left[\mathrm{Co}^{\mathrm{II}}(\mathrm{L})\right]+\mathrm{X}^{-}+\mathrm{R}^{\cdot} \text { (Outer-sphere }\right)
\end{aligned}
$$

Scheme 2. Cathodic reduction of $\mathrm{Co}(\mathrm{bpy}) 3^{2+}$ complex involving a loss of a bipyridyl ligand.

$$
\begin{aligned}
& \mathrm{Co}(\mathrm{bpy})_{3}{ }^{2+}+\mathrm{e}^{-} \rightleftharpoons \mathrm{Co}(\mathrm{bpy})_{3}{ }^{+} \\
& \mathrm{Co}(\mathrm{bpy})_{3}{ }^{+} \rightleftharpoons \mathrm{Co}(\mathrm{bpy})_{2}^{+}+\text {bpy }
\end{aligned}
$$

Scheme 3: Structure of the pesticides involved in this study and of deschloroalachlor.<smiles>CCc1cccc(CC)c1N(COC)C(=O)CCl</smiles>

Alachlor 1<smiles>Cc1cccc(C)c1N(Cc1ccn[nH]1)C(=O)CCl</smiles>

Metazachlor 2<smiles>CCc1cccc(C)c1N(C(=O)CCl)C(C)COC</smiles>

Metolachlor 3<smiles>O=C(O)COc1ccc(Cl)cc1Cl</smiles>

2,4-D 4<smiles>CCc1cccc(CC)c1N1COCCC1=O</smiles>

Deschloroalachlor 5

Scheme 4: Synthesis of the $\left[\mathrm{Co}\left(\operatorname{bpy}\left(\mathrm{CH}_{2} \mathrm{OH}\right)_{2}\right)_{2}\right]^{2+}$ complex.

$\mathrm{HOOC}$

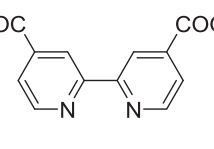

$$
\underset{\mathrm{H}_{2} \mathrm{SO}_{4}, \Delta}{\stackrel{\mathrm{EtOH}}{\longrightarrow}}
$$

EtOOC

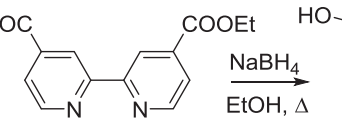

7

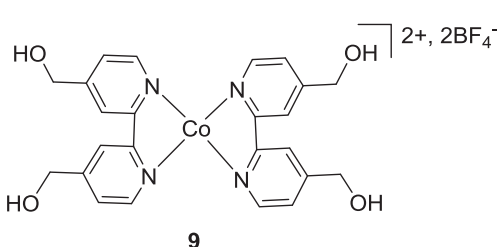

Scheme 5. Outer-sphere mechanism considered for the catalytic reduction of alachlor by the $\left[\mathrm{Co}\left(\text { bpy }\left(\mathrm{CH}_{2} \mathrm{OH}\right)_{2}\right)_{2}\right]^{2+}$ complex to simulate cyclic voltammograms.

$$
\begin{aligned}
& {\left[\mathrm{Co}(\mathrm{bpy})_{2}\right]^{2+}+\mathrm{e}^{-} \rightleftharpoons\left[\mathrm{Co}(\mathrm{bpy})_{2}\right]^{+} \quad k_{s}} \\
& {\left[\mathrm{Co}(\mathrm{bpy})_{2}\right]^{+}+\mathrm{RX} \longrightarrow\left[\mathrm{Co}(\mathrm{bpy})_{2}\right]^{2+}+\mathrm{X}^{-}+\mathrm{R}^{-} \quad k_{1}} \\
& {\left[\mathrm{Co}(\text { bpy })_{2}\right]^{+}+\mathrm{R} \longrightarrow\left[\mathrm{Co}(\mathrm{bpy})_{2}\right]^{2+}+\mathrm{R}^{-} \quad k_{2}}
\end{aligned}
$$


Table 1. Alachlor electrolysis performed at $-1.65 \mathrm{~V} / \mathrm{MSE}$ in aqueous medium

\begin{tabular}{|l|l|l|l|l|l|}
\hline Experiment & Substrate/catalyst ratio & Alachlor conc./mol L & Time/h & Conversion/\% & Yield of $\mathrm{Cl}^{-\mathrm{a}} / \%$ \\
\hline Entry 1 & No catalyst & $3.7 \times 10^{-4}$ & 1 & 27 & 25 \\
\hline Entry 2 & 3 & $3.7 \times 10^{-4}$ & 1 & 100 & 100 \\
\hline Entry 3 & 4 & $3.7 \times 10^{-4}$ & 1 & 99.6 & 93 \\
\hline
\end{tabular}

${ }^{\mathrm{a}}$ measured by ion chromatography 